\title{
NATURAL HERBICIDAL POTENTIAL OF SELECTED PLANTS ON GERMINATION AND SEEDLING GROWTH OF WEEDS
}

\author{
ANWAR, T. ${ }^{1 *}$ - ILYAS, N. ${ }^{1}$ - QURESHI, R. ${ }^{1}$ - QURESHI, H. ${ }^{1}-$ KHAN, S. ${ }^{2}-$ KHAN, S. A. ${ }^{3}-$ \\ FATIMAH, $\mathrm{H}^{4}{ }^{4}$ - WASEEM, $\mathrm{M}^{4}$ \\ ${ }^{I}$ Department of Botany, Pir Mehr Ali Shah Arid Agriculture University, Murree Road, \\ Shamsabad, Rawalpindi, 46300 Punjab, Pakistan \\ ${ }^{2}$ Department of Environmental Science, Gomal University, Dera Ismail Khan, 29050 Khyber \\ Pakhtunkhwa, Pakistan \\ ${ }^{3}$ Department of Earth and Environmental Science, Bahria University, Islamabad Campus \\ Shangrilla Road, Sector E-8, Islamabad 44000, Pakistan \\ ${ }^{4}$ Department of Biology, Allama Iqbal Open University, H-8, Islamabad 44000, Pakistan. \\ *Corresponding author \\ e-mail: drtauseefanwar@yahoo.com; phone: +92-333-686-0562
}

(Received $14^{\text {th }}$ Mar 2019; accepted $1^{\text {st }}$ May 2019)

\begin{abstract}
Use of synthetic herbicides is increasing globally. Application of heavy doses of herbicides is directly / indirectly causing negative impact on crop quality, human health and environment. Allelopathic weeds have wide application prospects in increasing crop production, plant protection and biological control. Current study was conducted to evaluate allelopathic activity of aqueous extracts of Carica papaya, Lantana camara, Rhazya stricta and Pinus roxburghii against selected weeds viz. Phalaris minor, Avena fatua, Chenopodium album, Euphorbia helioscopia and Rumex dentatus on filter paper, soil and agar at $100 \%, 75 \%, 50 \%$ and $0 \%$ concentration. Germination percentage $(\%)$, radicle length $(\mathrm{cm})$ and plumule length $(\mathrm{cm})$ were parameters to assess allelopathic potential. The STATISTIX 9 software was used to analyse data. Based on results, it was concluded that aqueous extract of $R$. stricta, P. roxburghii, C. papaya and $L$. camara possess potential inhibitory effects amongst which $L$. camara showed most prominant inhibitory effects towrads weeds. The germination and growth inhibition effects were found in order $L$. camara $>P$. roxburghii $>R$. stricta $>C$. papaya. Detailed field study is recommended to establish allelopathic potential of these species.
\end{abstract}

Keywords: food security, allelopathic potential, weed management, growth retardation, aqueous extract, natural herbicides

\section{Introduction}

Food production must increase by $70 \%$ to feed world population that is expected to reach 9.6 billion by 2050 . This challenge is even greater, when we take into account the scarcity of new arable land, the effects of climate change on agricultural production and the societal demand for decreasing the environmental impact of agriculture. Weed management will be of crucial importance, given that crop yield losses caused by weeds (about 32\%) are higher than those caused by either pathogens (15\%) or pests (18\%) (Van Evert et al., 2016). Several studies have reported significant yield losses in corn due to weed competition. Edalat et al. (2011) estimated a global $10 \%$ loss of agricultural production due to competitive effect of weeds.

Wheat (Triticum aestivum L.) is one of the most important cereal crop of the world. Its role is quite important in provision of human nutrition. Its contents comprise starch (59-89\%), protein (10-15.4\%), fats (1.4-2.1\%), inorganic ions (1.3-2.2\%), vitamin E, and vitamin Bcomplex. Wheat provides about $73 \%$ of caloric portion of a person's average diet (Rueda-Ayala 
et al., 2011). The average annual production of wheat is quite low in Pakistan compared to other agricultural economies. There are two ways for increasing wheat production; (1): by increasing cultivation area (2): by increasing yield per hectare. The first option is not practicable due to limited availability of land and irrigation water. Therefore, wheat production in Pakistan can only be increased by getting higher yield per hectare. There are many factors, which cause dcrease wheat production e.g., delayed sowing, less amount of fertilizers and weed interference. Weed infestation is serious threat to wheat production (Khan et al., 2016). In Pakistan, weeds cause about $45 \%$ loss in wheat production. Grain produce in Pakistan can be increased up to $41 \%$ if weeds are managed properly (Anwar et al., 2019). If weed management strategies are not devised, greater production losses in wheat yield can take place.

Traditional methods of weed control are time consuming and laborious. Although chemical control may enhance crop production, but concurrently effect the environment and human health. In addition, heading up of synthetic herbicide resistant weeds is another area of concern (Arafat et al., 2015). Herbicide remnants in crops, soil and underground water, cause evolution of resistant weed biotypes and are linked to health threats. Due to negative effect of synthetic chemicals, we are in demand of new classes of chemicals, especially, biodegradable products such as those originating from plants, which have the potential of being developed as herbicides (Aryakia et al., 2015). Allelopathy is a natural and eco-friendly technique. This strategy might be one of the very efficient tools for weed management and thereby increasing crop production (Kamran et al., 2017). Allelochemicals could be obtained from different tissues (flower, roots, stem and leaves) of plants (Zhou et al., 2004). These chemicals have capacity of producing wide array of biological effects and are quite useful for weed control processes (Ahmed et al., 2014). Natural herbicides obtained from allelopathic plants can help in reducing usage of synthetic herbicides. Natural herbicides will cause less pollution as well as alleviate human health concerns. The most commonly available allelochemicals are cinnamic and benzoic acids, alkaloids, flavonoids, phenolics, glucosionates and terpenes (Khan et al., 2014).

Keeping all this in view, present study conducted to evaluate Rhazya stricta Decne, Lantana camara L., Carica papaya L. and Pinus roxburghii Sarg. for allelopathic activity against major weeds of wheat crop viz. Phalaris minor, Avena fatua, Chenopodium album, Euphorbia helioscopia and Rumex dentatus. Selection of the plants was baseed on available literature about allelopathy of these plants (Qureshi et al., 2014; Sharma et al., 2016; Garima and Devi, 2017; Alqarawi et al., 2018).

\section{Materials and methods}

Allelopathic potential of leaves of selected plants viz., $R$. stricta, P. roxburgii, C. papaya, $L$. camara was evaluated. Fresh leaves for each species were collected, washed under running tap water and dried at $30^{\circ} \mathrm{C}$ in laboratory. Dried leaves were crushed using heavy duty blender to make fine powder (mesh size $2 \mathrm{~mm}$ ) and preserved in air tight plastic zip lock bags. Seeds of test weeds viz. Phalaris minor, Avena fatua, Chenopodium album, Euphorbia helioscopia and Rumex dentatus were procured from the Barani Agricultural Research Institute (BARI), Pakistan. Seeds were surface sterilized by $2 \%$ solution of Sodium hypochlorite (Biljana and Kragujevac, 2015).

Dried leaf powder of each plant species $(10 \mathrm{gm})$ was soaked in $100 \mathrm{ml}$ distilled water and agitated for 24 hours on orbital shaker $\left(25^{\circ} \mathrm{C} ; 160 \mathrm{rpm}\right)$. The filtrate was obtained through Whatman filter paper No. 1. The final volume of filtrate was adjusted to $100 \mathrm{ml}$ that gave $10 \%$ water extract as stock solution. Three concentrations i.e. $\mathrm{T}_{1}(0 \%), \mathrm{T}_{2}(50 \%), \mathrm{T}_{3}(75 \%)$ while $\mathrm{T}_{4}$ $(100 \%)$ were further prepared. Bioassays were carried out using soil and filter paper as medium. 
An aliquot (15 ml) of extract for each of three concentrations was added on $25 \mathrm{~g}$ soil per petri dish while $5 \mathrm{ml}$ extract on filter paper per petri dish. Ten seeds of weed test species were used per petri dish. Each treatment was replicated three times. The petri dishes were wrapped with aluminium foil and incubated in growth chamber (NTS Model MI-25S set at $28^{\circ} \mathrm{C}$ ) for 15 days (Anwar et al., 2017). The germination percentage (\%), lengths of radicle and plumule (cm) was calculated by comparing to control (Maharjan et al., 2007). The statistical analysis was carried out using STATISTIX 9 and means were separated by Fisher's protected LSD test (Nekonam et al., 2014).

\section{Results and Discussion}

\section{Allelopathic potential of $R$. stricta}

The results showed that $R$. stricta aqueous extract inhibited seed germination of $C$. album (35\%) followed by $R$. dentatus (32\%) and $P$. minor (31\%) on filter paper, whereas, there was non-significant effect on germination percentage of $A$. fatua and $E$. helioscopia. Similarly, $R$. stricta aqueous extract on soil inhibited seed germination of $R$. dentatus (40\%), C. album (39\%) and $P$. minor (37\%). Maximum (96\%) seed germination was observed for $A$. fatua and $E$. helioscopia while minimum seed germination was noted for C. album $(65 \%)$ and $R$. dentatus $(60 \%)$ on filter paper and soil, respectively. It indicated inhibitory compounds in leaves of $R$. stricta. The results agree with Chon et al. (2005) who proposed growth reduction in test species by toxic compounds in $R$. stricta leaf aqueous extract. Maximum radicle length inhibition was shown by $R$. dentatus (44\%) and $A$. fatua (40\%) by $R$. stricta aqueous extract on filter paper. Likewise, extract on soil caused radicle length reduction of $R$. dentatus (48\%) followed by $A$. fatua $(45 \%)$. Radicle length of $C$. album, $P$. minor and $E$. helioscopia remained unaffected. The minimum radicle length was observed for $R$. dentatus (56\% and 52\% on filter paper and soil, respectively) while maximum radicle length (97\%) was noted for $C$. album, P. minor and $E$. helioscopia. Aqueous extract of $R$. stricta significantly inhibited the plumule length of $A$. fatua (27\%) and $R$. dentatus (25\%) on filter paper. Interestingly, there was no inhibitory effect on plumule of $P$. minor, E. helioscopia and C. album. R. stricta aqueous extract inhibited plumule length of $A$. fatua (33\%) and $R$. dentatus (28\%) in soil. Minimum plumule length was noted for T. aestivum (49\%) on filter paper and soil (45\%) while maximum plumule length was noted for P. minor, E. helioscopia and C. album (96\% for all) (Fig. 1). Wardle et al. (1992) noted that seed germination, radicle and plumule growth for grass weeds were significantly reduced by $R$. stricta extract. Similar results were reported by Assaeed and Al-Doss (1997) who reported inhibitory effect on germination rate and percentage of test species along morphological irregularities in radicle and plumule of test species (Farsetia aegyptia, Pennisetum divisum, Haloxylon salicornicum, Lasiurus scindicus) by leaves of $R$. stricta. Growth was significantly affected by allelopathic interaction on soil in contrast to filter paper as described by Hegazy and Fadl-Allah (1995) and El-Khatib (2000). While exploring possible mechanism of action, Alqarawi et al. (2018) reported growth and metabolism disfunctioning in $S$. villosa by $R$. stricta leaf aqueous extracts by hampering membrane functioning and photosynthetic capacity. Elkhawas and Shehata (2005) reported change in enzyme activities, which affect the transport of storage substances in seed during growth. Furthermore, toxic compounds in $R$. stricta extract affect osmotic factors (Assaeed and Al-Doss, 1997). 

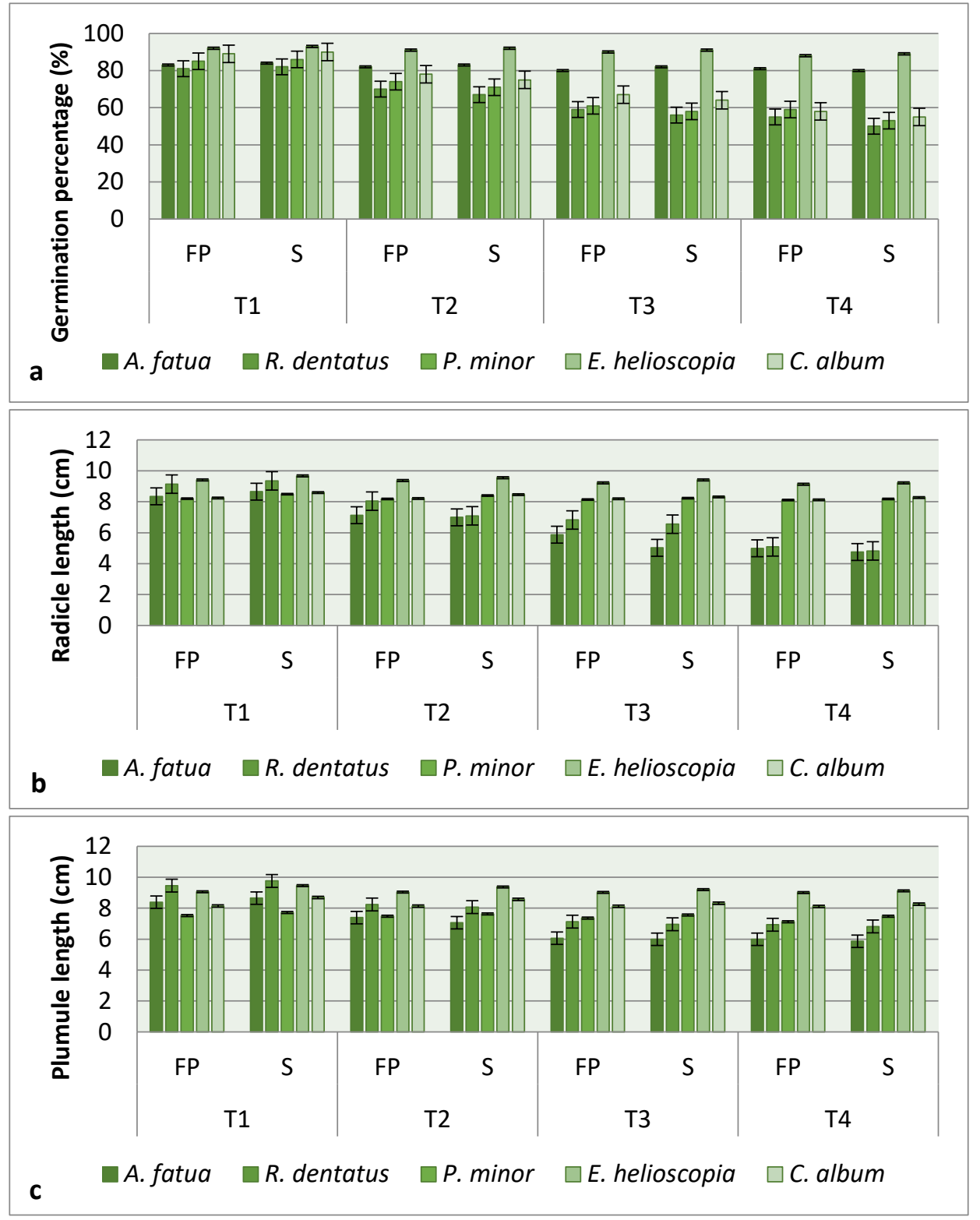

Figure 1. Allelopathic potential of R. stricta aqueous extract on (a): germination percentage, $(b)$ : radicle length (c): plumule length against test species on filter paper $(F P)$ and soil $(S)$ where; $T_{1}$ (control), $T_{2}(50 \%), T_{3}(75 \%)$ and $T_{4}(100 \%)$

\section{Allelopathic potential of L. camara}

L. camara aqueous extract inhibited seed germination of $R$. dentatus $(58 \%)$ followed by E. helioscopia (57\%), A. fatua (56\%) and P. minor $(55 \%)$ on filter paper and E. helioscopia (65\%) followed by P. minor (63\%), R. dentatus (61\%), A. fatua (60\%) on soil. Maximum (96\%) germination was observed for $C$. album while minimum for A. fatua (42\%) and E. helioscopia (35\%) on filter paper and soil, respectively. Jabeen and Ahmed (2009) found germination and growth inhibition in Cucurbita pepo by allelopathic action of $L$. camara leaf aqueous extract. Highest radicle length inhibition was exhibited by A. fatua (52\%), P. minor (51\%) and C. album (50\%) on filter paper, while on soil extract caused significant radicle length reduction of $A$. fatua (54\%), 
P. minor (53\%) and C. album (52\%). Minimum radicle length was noted for A. fatua i.e. $48 \%$ and $46 \%$ on filter paper and soil, respectively. Maximum radicle length was noted for $R$. dentatus and E. helioscopia (97\% for each). Aqueous extract of L. camara inhibited plumule length of E. helioscopia (52\%), A. fatua (51\%), R. dentatus (50\%) and C. album $(50 \%)$ on filter paper. There was no significant effect on plumule elongation of $P$. minor. Likewise, L. camara aqueous extract inhibited plumule length of E. helioscopia (56\%), C. album (55\%), R. dentatus (53\%) and A. fatua (53\%) on soil. Minimum plumule length was noted for E. helioscopia i.e. $48 \%$ and $44 \%$ on filter paper and soil, respectively. Maximum plumule length (96\%) was noted for P. minor (Fig. 2).
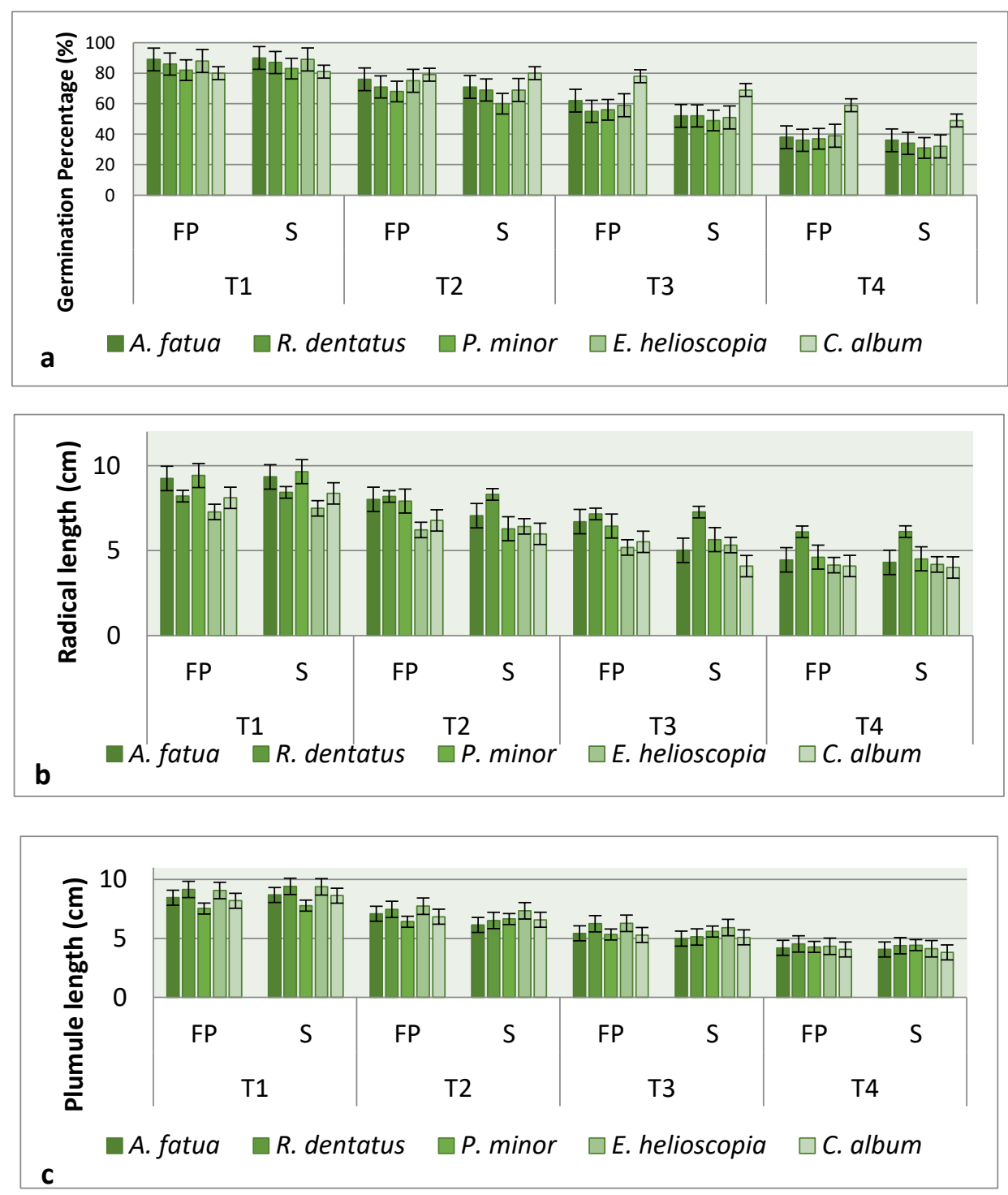

Figure 2. Allelopathic potential of L. camara aqueous extract on (a): germination percentage, $(b)$ : radicle length $(c)$ : plumule length against test species on filter paper $(F P)$ and soil $(S)$ where; $T_{1}$ (control), $T_{2}(50 \%), T_{3}(75 \%)$ and $T_{4}(100 \%)$

Tadele (2014) described concentration dependent and species-specific allelopathic potential of leaf aqueous extract of $L$. camara on root and shoot elongation. The aqueous 
extract of L. camara suppressed seed germination and growth of different agricultural crops (Sharma et al., 2005; Ahmed et al., 2007). These results were in accordance to Hussain et al. (2011) and Iramus et al. (2011) who noted retardation in root length of Vigna radiata due to inhibitory potential of $L$. camara leaf extract. Enyew and Raja (2015) observed significant retardation in root elongation by $L$. camara leaf aqueous extract in Zea mays. Aqueous extracts from L. camara leaves caused tissues decay, damages, and subsequent retarded growth of Eichhornia crassipes (Saxena, 2000).

\section{Allelopathic potential of C. papaya}

C. papaya aqueous extract inhibited germination percentage of E. helioscopia (35\%) followed by P. minor (33\%) and A. fatua (32\%) on filter paper. Similarly, on soil, seed germination of $P$. minor (40\%) was inhibited followed by A. fatua $(39 \%)$ and E. helioscopia (38\%). Maximum (96\%) germination was observed for R. dentatus and $C$. album. Minimum germination was noted for E. helioscopia $(65 \%)$ and $P$. minor $(60 \%)$ on filter paper and soil, respectively. Highest radicle length inhibition was exhibited by $P$. minor (36\%) and $R$. dentatus (35\%) in $C$. papaya aqueous extract on filter paper. Likewise, extract on soil caused significant radicle length reduction of P. minor (43\%) and R. dentatus (40\%). Radicle length of C. album, A. fatua and E. helioscopia remained unaffected. Maximum radicle length $(97 \%)$ was noted for C. album, A. fatua and E. helioscopia. The aqueous extract of $C$. papaya inhibited plumule length of $P$. minor (34\%) and C. album (33\%) on filter paper. C. papaya aqueous extract significantly inhibited plumule length of $C$. album (43\%) and $P$. minor (42\%) on soil. Minimum plumule length was noted for P. minor $(66 \%)$ and $C$. album (57\%) on filter paper and soil. Maximum plumule length (96\%) was noted for A. fatua, $R$. dentatus and E. helioscopia (Fig. 3). Wabo et al. (2011) studied root and shoot elongation inhibition along germination of Lactuca sativa seedling that was significantly checked by $C$. papaya aqueous extract. Beneficial secondary metabolites such as chlorogenic acid, quercetin, kaempferol, caffeic acid, p-coumaric acid and protocatechuic acid had reported from $C$. papaya that might be responsible for its phytotoxic/allelopathic potential (Canini et al., 2007). Many of those phenolics have been described as allelochemicals (Miean et al., 2001).

\section{Allelopathic potential of $P$. roxburghii}

Aqueous extract of $P$. roxburghii needles inhibited germination percentage of C. album and A. fatua by $54 \%, 48 \%$ and $43 \%$, respectively on filter paper. Similarly, $P$. roxburghii aqueous extract on soil inhibited seed germination of $C$. album and A. fatua by $50 \%$ and $44 \%$, respectively. Maximum (98\%) germination was observed for $R$. dentatus, $P$. minor and $E$. helioscopia. The aqueous extract of $P$. roxburghii exhibited radicle length inhibition of $C$. album (40\%) followed by $R$. dentatus (39\%) on filter paper, whereas, no significant effect was noted for P. minor, E. helioscopia and A. fatua. Similarly, application of extract to soil suppressed radicle length of $C$. album and $R$. dentatus by $46 \%$ and $41 \%$, respectively. Maximum (98\%) radicle length was observed for P. minor, E. helioscopia and A. fatua. Minimum radicle length was noted for $C$. album i.e. $60 \%$ and $54 \%$ on filter paper and soil, respectively. The aqueous extract of $P$. roxburghii inhibited the plumule length of A. fatua (38\%) and $R$. dentatus (34\%) on filter paper. 

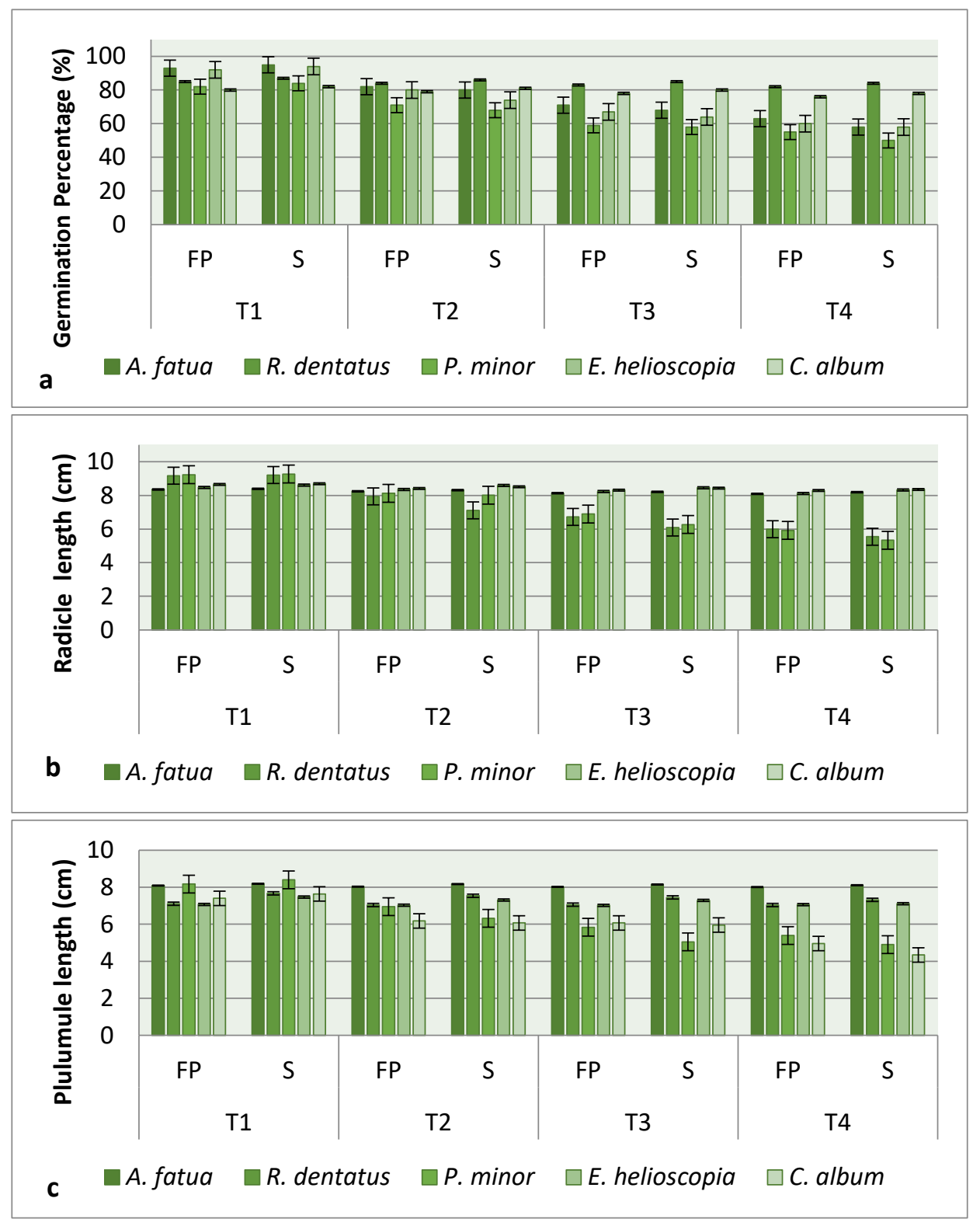

Figure 3. Allelopathic potential of C. papaya aqueous extract on (a): germination percentage, $(b)$ : radicle length $(c)$ : plumule length against test species on filter paper $(F P)$ and soil $(S)$ where; $T_{1}$ (control), $T_{2}(50 \%), T_{3}(75 \%)$ and $T_{4}(100 \%)$

Likewise, $P$. roxburghii aqueous extract inhibited plumule length of $A$. fatua (40\%) and $R$. dentatus (39\%) in soil. Maximum plumule length (98\%) was noted for $P$. minor, E. helioscopia and C. album while minimum plumule length was noted for A. fatua showing $62 \%$ and $60 \%$ on filter paper and soil, respectively (Fig. 4). Maximum germination was observed for $R$. dentatus, $P$. minor and $E$. helioscopia. Maximum radicle length was observed for $P$. minor, E. helioscopia and $A$. fatua. Minimum radicle length was noted for C. album. Maximum plumule length was noted for P. minor, E. helioscopia and $C$. album. Minimum plumule length was noted for A. fatua. Aqueous extract of $P$. roxburghii needles suppressed growth of mustard and wheat seedlings while that of $P$. brutia needles suppressed growth of Lolium multiflorum and Poa pratensis seedlings 
(Baroniya and Baroniya, 2014). Current study is in accordance with Singh et al. (2001) who determined seedling growth and seed germination of Capsicum annuum, Pisum sativum and Oryza sativa was retarded by Pinus needles. Likewise, results were explained by Madgil and Kapil (1990) for Amaranthus paniculatus and Trifolium pratense seeds treated with leaf extract of $P$. roxburghii. Kil and Yim (1983) observed that toxic compounds produced by $P$. densiflora checked seed germination and growth of species. The phenolic composites of $P$. rigida exhibited retardation effect on Cassia mimosoides. Fresh, senesced, and decaying needles from $P$. halepensis exhibit potent inhibitory potential on Festuca arundinacea, Cyanodon dactylon, Avena sativa and Lemna minor (Nektarios et al., 2005).

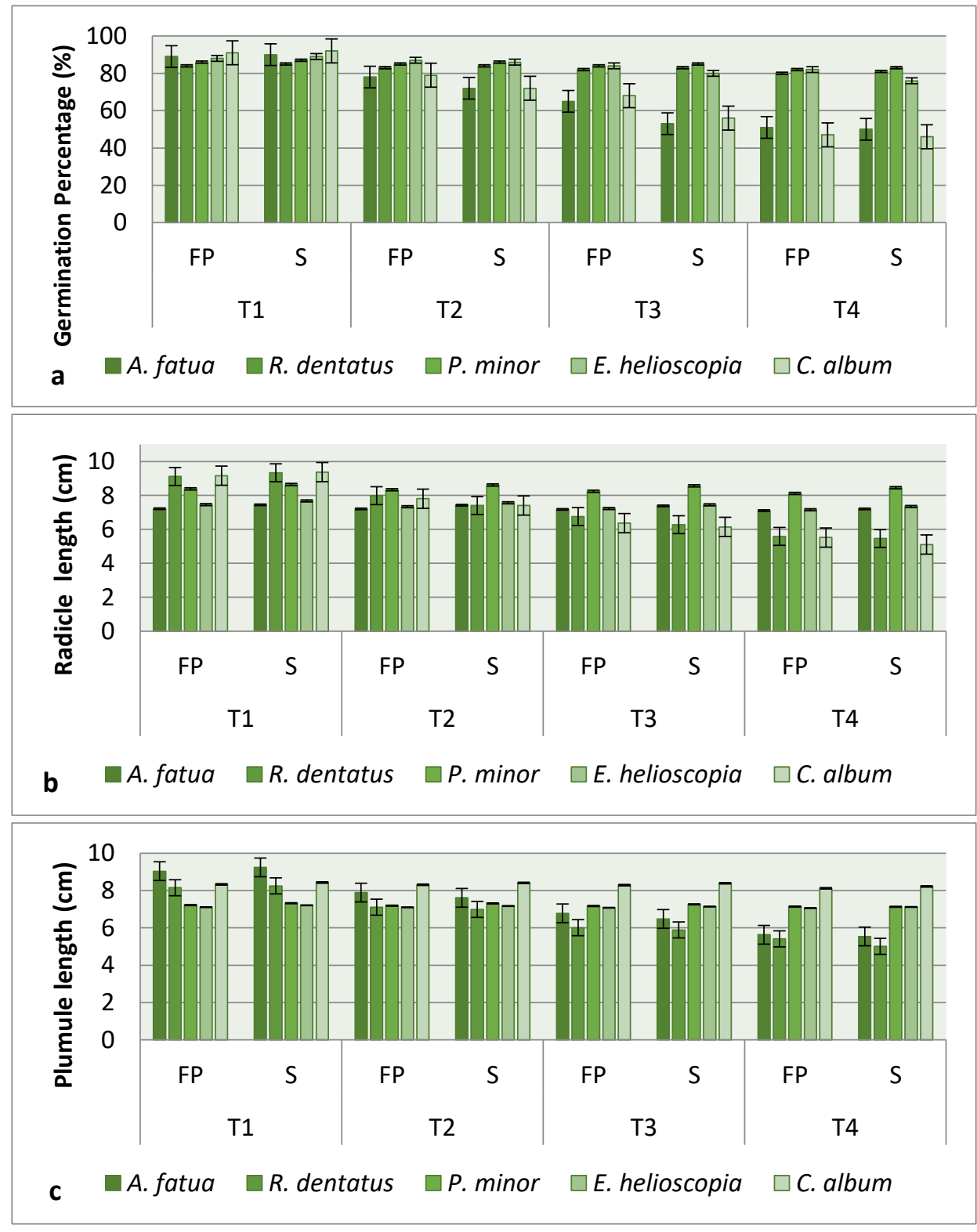

Figure 4. Allelopathic potential of L. camara aqueous extract on (a): germination percentage, (b): radicle length $(c)$ : plumule length against test species on filter paper $(F P)$ and soil $(S)$ where; $T_{1}$ (control), $T_{2}(50 \%), T_{3}(75 \%)$ and $T_{4}(100 \%)$ 
The germination and growth inhibition effects were found in order L. camara $>$ P. roxburghii $>R$. stricta $>C$. papaya. Relatively greater (but statistically nonsignificant) values for germination and growth inhibition were recorded on soil medium compared to filter paper.

\section{Conclusions}

Present results indicated that aqueous extract of selected plants at higher concentrations reduce the seed germination, radicle and plumule length of weeds associated with the wheat crop. Results provide evidence about herbicidal potential of test species viz. L. camara, $P$. roxburghhii, C. Papaya and $R$. stricta against weeds of wheat crop (Avena fatua, Phalaris minor, Chenopodium album and Rumex dentatus). Further work is needed to appraise the potential inhibitory effects of allelochemicals from these plants.

\section{REFERENCES}

[1] Ahmed, R., Uddin, M. B., Khan, M. A., Mukul, S. A., Hossain, M. K. (2007): Allelopathic effects of Lantana camara on germination and growth behavior of some agricultural crops in Bangladesh. - J. For. Res. 18: 301-304.

[2] Ahmed, S. A., El-Rokiek, K. G., El-Masry, R. R., Messiha, N. K. (2014): The efficiency of allelochemicals in the seed powder of Eruca sativa in controlling weeds in Pisum sativum. - Middle East Journal of Agricultural Research 3: 757-762.

[3] Alqarawi, A. A., Hashem, A., Kumar, A., Al-Arjani, A. F., Abd-Allah, E. F., Dar, B. A., Wirth, S., Davranov, K., Egamberdieva, D. (2018): Allelopathic effects of the aqueous extract of Rhazya stricta on growth and metabolism of Salsola villosa. - Plant Biosystems 152: 1263-1273.

[4] Anwar, T., Ilyas, N., Qureshi, R., Qureshi, H., Gilani, N., Khan, S., Khan, S. A., Fatimah, H., Waseem, M., Mahmood, R. T., Maqsood, M. (2019): comparative allelopathic activity of Rhazya stricta, Pinus roxburghii, Carica papaya and Lantana camara against noxious weeds. - Appl. Ecol. Env. Sci. 17: 7175-7187.

[5] Anwar, T., Khalid, S., Mazhar, R., Qureshi, H., Rashid, M. (2017): Herbicidal potential of selected species to overcome weed infestation in Triticum aestivum, Zea mays and Helianthus annuus. - Pak. J. Weed Sci. Res. 23: 49-63.

[6] Arafat, Y., Khalid, S., Lin, W., Fang, C., Sadia, S., Ali, N., Azeem, S. J. (2015): Allelopathic evaluation of selected plants extract against broad and narrow leaves weeds and their associated crops. - Academic J. Agric. Res. 3: 226-234.

[7] Aryakia, E., Naghavi, M. R., Farahmand, Z., Fazeli, S. A. S. (2015): Evaluating allelopathic effects of some plant species in tissue culture media as an accurate method for selection of tolerant plant and screening of bioherbicides. - J. Agric. Sci. Technol. 17: 1011-1023.

[8] Assaeed, A. M., Al-Doss, A. A. (1997): Allelopathic effects of Rhazya stricta on seed germination of some range plant species. - Annals Agric. Sci. 42: 159-167.

[9] Baroniya, S. S., Baroniya, M. B. (2014): Germination and early seedling growth of mustard and wheat as affected by allelopathic activity of Pinus needle extracts. - Int. Res. J. Environ. Sci. 3: 27-34.

[10] Biljana, M. B., Kragujevac, D. Z. J. (2015): Allelopathic relations of selected cereal and vegetable species during seed germination and seedling growth. - J. Sci. 37: 135-142.

[11] Canini, A., Alesiani, D., Arcangelo, G., Tagliatesta, P. (2007): Gas Chromatography-Mass Spectrometry analysis of phenolic compounds from Carica papaya L. leaf. - J. Food Compos. Anal. 20: 584-590. 
[12] Chon, S. U., Jang, H. G., Kim, D. K., Kim, Y. M., Boo, H. O., Kim, Y. J. (2005): Allelopathic potential in lettuce (Lectuca sativa L.). - Plant Science and Horticulture 206: 309-317.

[13] Edalat, M., Ghadiri, H., Hamzehzarghani, H., Kazemeini, S. A. (2011): Prediction of corn yield loss due to different redroot pigweed density and irrigation level using empirical models. - Australian J. Crop Sci. 5(2): 187-196.

[14] El-Khatib, A. A. (2000): The ecological significance of allelopathy in the community organization of allhagrae- corum. - Biological Plantarum 43: 42-431.

[15] El-Khawas, S. A., Shehata, M. M. (2005): The allelopathic potentialities of Acacia nilotica and Eucalyptus rostrata on monocot (Zea mays L.) and Dicot (Phaseolus vulgarise L.). Plant Biotechnol. 4: 23-34.

[16] Enyew, A., Raja, N. (2015): Allelopathic effect of Lantana camara L. leaf powder on germination and growth behavior of maize, Linn. and wheat, Triticum turgidum Linn. cultivars. - Asian J. Agric. Res. 7: 4-10.

[17] Garima, Devi, M. (2017): Allelopathy in agroforestry: A review. - J. Pharmacognos. Phytochem. 6(3): 686-688.

[18] Hegazy, A. K., Fadl-Allah, E. M. (1995): Inhibition of seed germination and seedling growth by Cleome droserifolia and allelopathic effect on fungi. - Egypt. J. Arid Environ. 29: 3-13.

[19] Hussain, M. I., González, L., Reigosa, M. J. (2011): Allelopathic potential of Acacia melanoxylon on the germination and root growth of native species. - Weed Biol. Manag. 11: 18-28.

[20] Iramus, S., Moinuddin, A., Syed, T. A. (2011): Allelopathic effect of scarlet pimpernel (Anagallis arvensis) on seed germination and radicle elongation of mung bean and pearl millet. - Pak. J. Bot. 43: 351-355.

[21] Jabeen, N., Ahmed, M. (2009): Possible allelopathic effect of three different weeds on germination and growth of maize (Zea mays) cultivars. - Pak. J. Bot. 41: 1677-1683.

[22] Kamran, M., Raza, A., Ali, Q., Ali, H. H., Chattha, M. S. (2017): Investigating the influence of fertilizer and allelopathic water extracts on maize and associated weeds. - Pak. J. Weed Sci. Res. 23: 361-378.

[23] Khan, I., Ali, Z., Khan, M. I., Hussain, Z., Khan, I. A., Waqas, M., Khan, R., Khan, S. (2014): Allelopathic effects of some weeds on chickpea crop. - Pak. J. Weed Sci. Res. 20: 207-211.

[24] Khan, R., Khan, M. A., Shah, S., Uddin, S., Ali, S., Ilyas, M. (2016): Bioherbicidal potential of plant extracts against weeds of wheat crop under agro-climatic conditions of Peshawar-Pakistan. - Pak. J. Weed Sci. Res. 22: 285-294.

[25] Kil, S. B., Yim, Y. J. (1983): Allelopathic effects of Pinus densiflora on undergrowth of red pine forest. - J. Chem. Ecol. 9: 1135-1151.

[26] Madgil, D., Kapil, M. (1990). Allelopathic activity of Pinus roxburghii Sarg. and Rhododendron arboreum Sm. leaves. - Indian Forest 116: 512-514.

[27] Maharjan, S., Shrestha, B. B., Jha, P. K. (2007): Allelopathic effects of aqueous extract of Parthenium hysterophorus L. on seed germination and seedling growth of some cultivated and wild herbaceous species. - Sci. World 5: 35-39.

[28] Miean, K., Mohamed, H., Flavanoid, S. (2001): Myricetin, Quercetin, Kaempferol, Luteolin, and Apigenin: Content of edible tropical plants. - J. Agric. Food Chem. 49: 31063112 .

[29] Nekonam, M. S., Kraimmojeni, H., Sharifnabi, B., Razmjoo, J., Amini, H., Bahrami, F. (2014): Assessment of some medicinal plants for their allelopathic potential against redroot pigweed (Amaranthus retroflexus). - J. Plant Prot. Res. 54: 90-95.

[30] Nektarios, P. A., Economou, G., Avgoulas, C. (2005): Allelopathic effects of Pinus halepensis needles on turfgrasses and biosensor plants. - Hortscience 40: 246-250. 
[31] Qureshi, H., Arshad, M., Bibi, Y. (2014): Toxicity assessment and phytochemical analysis of Broussonetia papyrifera and Lantana camara: Two notorious invasive plant species. J. Biodivers. Environ. Sci. 5(2): 508-517.

[32] Rueda-Ayala, V. P., Rasmussen, J., Gerhards, R., Fournaise, N. E. (2011): The influence of post-emergence weed harrowing on selectivity, crop recovery and crop yield in different growth stages of winter wheat. - Weed Res. 51: 478-488.

[33] Saxena, M. K. (2000): Aqueous leachate of Lantana camara kills water hyacinth. - J. Chem. Ecol. 26: 2435-2447.

[34] Sharma, G. P., Raghubanshi, A. S., Sing, J. S. (2005): Lantana invasion: an overview. Weed Biol. Manag. 5: 157-167.

[35] Sharma, N. K., Batish, D. R., Singh, H. P., Kohli, R. K. (2016): Allelopathic effect of Pinus roxburghii on an understorey plant Bidens pilosa. - Annals Plant Sci. 5(10): 1446-1450.

[36] Singh, H. P., Kohli, R. K., Batish, D. R. (2001): Allelopathic interference of Populus deltoids with some winter season crops. - Agronomy 21: 139-146.

[37] Tadele, D. (2014): Allelopathic Effects of Lantana (Lantana camara L.) leaf extracts on germination and early growth of three agricultural crops in Ethiopia. - Momona Ethiopian J. Sci. 6: 111-119.

[38] Van Evert, F. K., Fountas, S., Jakovetic, D., Crnojevic, V., Travlos, I., Kempenaar, C. (2016): Big data for weed control and crop protection. - Weed Res. https://doi.org/10.1111/wre.12255.

[39] Wabo, P. J., Ngankam, N. J. D., Bilong, B. C. F., Mpoame, M. (2011): A comparative study of the ovicidal and larvicidal activities of aqueous and ethanolic extracts of pawpaw seeds Carica Papaya (Caricaceae) on Heligmosomoides Bakeri. - Asian Pac. J. Trop. Med. 24: 447-450.

[40] Wardle, D. A., Nicholson, K. S., Ahmed, M. (1992): Comparison of osmotic and allelopathic effects of grass leaf extracts on grass seed germination and radicle elongation. - Plant and Soil 140: 315-319.

[41] Zhou, Y. H., Yu, J. Q., Huang, L. F., Nogues, S. (2004): The relationship between $\mathrm{CO}_{2}$ assimilation, photosynthetic electron transport, and water-water cycle in chill-exposed cucumber leaves under low light and subsequent recovery. - Plant Cell Environ. 27: 15031514. 